Relations industrielles

Industrial Relations

\title{
Ferner, A., and R. Hyman (eds.), Changing Industrial Relations
} in Europe

\section{P.B. Beaumont}

Volume 54, numéro 2, 1999

URI : https://id.erudit.org/iderudit/051241ar

DOI : https://doi.org/10.7202/051241ar

Aller au sommaire du numéro

\section{Éditeur(s)}

Département des relations industrielles de l'Université Laval

\section{ISSN}

0034-379X (imprimé)

1703-8138 (numérique)

Découvrir la revue

Citer ce compte rendu

Beaumont, P. (1999). Compte rendu de [Ferner, A., and R. Hyman (eds.),

Changing Industrial Relations in Europe]. Relations industrielles / Industrial

Relations, 54(2), 415-416. https://doi.org/10.7202/051241ar

Tous droits réservés @ Département des relations industrielles de l'Université Laval, 1999
Ce document est protégé par la loi sur le droit d'auteur. L’utilisation des services d’Érudit (y compris la reproduction) est assujettie à sa politique d'utilisation que vous pouvez consulter en ligne.

https://apropos.erudit.org/fr/usagers/politique-dutilisation/ 


\section{Recensions}

\section{Book Reviews}

\section{Changing Industrial Relations in Europe}

edited by A. FERNER and R. HYMAN, London: Blackwell, $2^{\text {nd }}$ edition, 1998, 550 p., ISBN 0-631-20551-9.

To many North American commentators there is a European industrial relations system characterized by high wages / high skills / high regulation. And to some individuals the high regulation feature has played a major role in accounting for the relatively high unemployment levels of Europe relative to the USA. In fact, recent research suggests that labour market regulation in Europe has only a relatively limited role in accounting for this high unemployment situation. This finding should surprise few people once it is fully appreciated just how heterogeneous is the nature of European industrial relations. And it was the first edition of this text (published in 1992) that provides the reader with an excellent feel for the extent and nature of such variation.

This new, second edition has, as its central theme, the changing nature of European industrial relations in the years 1992-97. Accordingly, as indicated in the editors' introductory chapter, the individual country studies have sought to concentrate on the following: the nature, and impact, of "internationalization"; the issue of decentralization and flexibility; the regulatory capacity of the nation state; and the capacity of national institutions to respond to transnational pressures. Some of the major findings and conclusions to emerge may be listed as follows. Firstly, the pressures of internationalization are important, but their industrial relations consequences are not uniform in direction or extent, with some national systems being more (less) vulnerable to them than others. Secondly, the perceived inevitable drive towards decentralization / flexibility is rather more problematic than many have suggested, with higher level co-ordination (in various forms) remaining in place, and even being strengthened in some cases. Thirdly, union membership declines continue, but unions have sought to adapt and change, with "institutional robustness" often being apparent if one looks beyond a simple collective bargaining focus. Fourthly, there have been important pressures on, and challenges to, the degree of autonomy, and hence regulatory capacity, of nation states, but again inevitable decline and decay are far from being the full story; central co-ordination has been revived in some countries. Finally, a combination of "procedural formalization and substantive flexibility" has been a noticeable adaptation to many ongoing pressures for change.

In a book consisting of 17 different country chapters there is inevitably considerable variation apparent between the contributions. The size of individual chapters varies a great deal (54 pages for Britain compared to 8 for Luxembourg), as does the content of the chapters. The latter reflects various influences, such as the disciplinary background of the authors, the availability and quality of information and data sources, and, of course, the extent and nature of recent changes in the systems concerned. It also has to be said that 
this variation seems to reflect the extent to which the authors have followed the editors' guidelines to cut back on historical material and concentrate on recent changes.

I have only a few minor "quibbles" about this book. A useful, but difficult, exercise would have been a concluding chapter seeking to summarize and distil what had gone before, although the editors' introduction does this to some extent. Secondly, a little stronger editorial control might have provided more of a common framework of discussion for individual chapters, as some rather "talk past each other". Thirdly, a little more emphasis on pan-European pressures and developments would have been welcomed in some chapters; EU-initiated develop- ments such as European works councils rarely got a mention in some cases.

However, there is no real question that this book provides the best, up-todate overview of changing European industrial relations at the present time. This edition does not cover the countries of Eastern Europe where things have not yet fully settled down; this being said, the German chapter does have some very useful material and insights on the East German scene. I, for one, hope and expect to see a third edition along these lines.

P. B. BEAUMONT

Department of Management Studies University of Glasgow

\section{Au-delà de l'emploi - Transformations du travail et devenir du droit du travail en Europe}

Rapport pour la Commission européenne sous la direction d'Alain SUPIOT, Paris : Flammarion, 1999, 321 p., ISBN 2-08212526-2.

Il s'agit de la version en langue française d'un rapport présenté à la Commission européenne par un groupe de neuf experts, de différentes nationalités européennes, dont le professeur Alain Supiot de l'Université de Nantes, rapporteur général. Ils avaient pour tâche de "réfléchir de manière prospective et constructive au niveau communautaire et dans un cadre interculturel et interdisciplinaire sur l'avenir du travail et du droit du travail [...] ». L'approche est à la fois transnationale - le rapport se fonde principalement sur les informations et les analyses des situations nationales correspondant à la nationalité des experts, transdisciplinaire - le droit ouvert sur une réalité sociale, qu'il contribue lui-même à transformer et diachronique - l'approche se veut soucieuse de replacer le changement dans sa perspective historique.

L'ampleur du sujet confère un intérêt particulier aux angles choisis pour l'appréhender. Les "percées " annoncées (p. 21) sont les suivantes: travail et pou- voir privé ; travail et statut professionnel ; travail et temps; travail et organisation collective et travail et pouvoirs publics. Lecture faite, il faut convenir de la réalité de leur interrelation. 11 en va de même de deux autres chapitres finaux concernant respectivement le travail des femmes (son contenu, si l'avis du rapporteur général avait prévalu, se serait intégré à celui des thèmes antérieurs) et le droit du travail et la performance économique. Cette dernière considération est primordiale : "La meilleure des sécurités est [...] celle qui s'appuie sur la création d'emplois" (p. 285).

Les premières démarches consistent donc à mesurer l'écart entre le modèle classique du salariat, à partir duquel s'était édifié un droit du travail tout aussi classique, aujourd'hui fortement remis en cause. "Travail et pouvoir privé" constatent à la fois les progrès de l'autonomie au travail et l'accentuation de la dépendance résultant de la fragmentation du travail. La question centrale est celle, 